\title{
Hemolytic Disease of the Newborn
}

National Cancer Institute

\section{Source}

National Cancer Institute. Hemolytic Disease of the Newborn. NCI Thesaurus. Code C101304.

A disorder of the fetus or newborn that occurs when fetal cells that are coated with IgG alloantibodies from the mother attack antigens inherited from the father. Severity can range from absence of symptoms to death. 